Published in final edited form as:

Prog Cardiovasc Dis. 2012 ; 55(1): 64-69. doi:10.1016/j.pcad.2012.06.003.

\title{
Transcriptomic Biomarkers of Cardiovascular Disease
}

\author{
Dawn M. Pedrotty, MD, PhD, Michael P. Morley, M.S, and Thomas P. Cappola, MD, ScM \\ Penn Cardiovascular Institute and Department of Medicine, Perelman School of Medicine, \\ University of Pennsylvania, Philadelphia, PA
}

\begin{abstract}
Transcriptomics is the study of how our genes are regulated and expressed in different biological settings. Technical advances now enable quantitative assessment of all expressed genes (i.e. the entire 'transcriptome') in a given tissue at a given time. These approaches provide a powerful tool for understanding complex biological systems and for developing novel biomarkers. This chapter will introduce basic concepts in transcriptomics and available technologies for developing transcriptomic biomarkers. We will then review current and emerging applications in cardiovascular medicine.
\end{abstract}

\section{Introduction}

Growing knowledge of genome structure and variation has spawned development of technologies that allow researchers to study thousands of genes, transcripts, and proteins simultaneously._This has expanded biomedical science beyond reductionist approaches that test the function of individual genes to less biased approaches that study the behavior of many or all genes in homeostasis and disease. At the same time, 'omics' approaches have begun to transform the way in which physicians approach the fundamental clinical tasks of risk assessment, diagnosis, prognosis, and treatment. For example, it is now well established that inherited variation in DNA sequence influences risk of common cardiovascular conditions such as coronary artery disease ${ }_{-}^{2}$ and heart failure. ${ }_{-}^{3}$ As such, a more personalized approach to clinical care based on genome sequencing is posited to be more effective. 4 Similarly, unbiased 'omic' approaches are revealing a host of new biomarkers that have the potential to improve assessment and treatment of cardiovascular disease. This article will review how one of these approaches, transcriptomics, has impacted the field of cardiovascular biomarkers over the past decade.

Correspondence: Thomas P. Cappola, MD, ScM 11-102 TRC 3400 Civic Center Blvd Philadelphia, PA 19104 Phone: (215) 573-4717 Fax: (215) 746-7415 thomas.cappola@uphs.upenn.edu.

Publisher's Disclaimer: This is a PDF file of an unedited manuscript that has been accepted for publication. As a service to our customers we are providing this early version of the manuscript. The manuscript will undergo copyediting, typesetting, and review of the resulting proof before it is published in its final form. Please note that during the production process errors may be discovered which could affect the content, and all legal disclaimers that apply to the journal pertain.

Disclosures: Dr. Cappola is an inventor on an unlicensed patent of gene expression assays for heart transplant rejection. 


\section{Transcriptomics}

The basic unit of inheritance is the gene, which is passed on to offspring as a specific sequence of DNA. Most genes exert their biological effects via transcription to messenger RNA (gene expression) in a tissue of interest. Regulation of gene expression is highly complex and underlies many fundamental biological processes such as growth, differentiation into organs and tissues, disease pathogenesis, and response to drug therapy. Unlike DNA sequence variation, which is normally fixed within an individual, there is tremendous variability in gene expression in different tissues and in response to stimuli.

Transcriptomics (sometimes referred to as gene expression profiling) is the quantitative study of all genes expressed in a given biological state. 5 Transcriptomic studies are performed through use of gene expression microarrays ${ }_{-}^{6}$ or RNA sequencing 7 to quantify the abundance of all transcripts expressed in a set of experimental samples. A common application of transcriptomics is to compare gene expression in diseased and non-diseased tissues to provide catalogue of genes that show altered expression in disease. These data can be utilized to identify individual genes that show large changes in disease, or to create a global profile or 'signature' comprised of multiple expression changes associated with disease. Such findings not only advance our understanding of disease pathogenesis, they also reveal transcripts that can be quantitatively assessed as new biomarkers.

Research over the past decade has revealed far more complexity than the original 'central dogma' that genes encoded by DNA are transcribed to RNA which is subsequently translated to protein (Figure). Gene transcriptionis regulated by a complex web of epigenetic factors, ${ }_{-}^{8}$ including transcription factor proteins that bind to specific DNA regulatory sequences, chemical modification of histones that affect DNA packaging, and chemical modification of DNA itself. During transcription, exons are variably spliced to create entire families of splice variants produced by a single gene. ${ }_{-}^{9}$ Exonic sequences themselves may be actively changed or 'edited' in going from DNA to RNA, providing another layer of complexity that has only been recently identified. ${ }^{10}$ Each mature transcript (messenger RNA, or mRNA) assumes a three dimensional structure which can affect efficiency of translation to functional protein. ${ }^{11}$ Finally, there are entire species of 'noncoding RNAs', such as microRNA (miR) 12 and long noncoding RNA(lncRNA) 13 among others, that do not encode protein, but can nevertheless have important regulatory functions. For example, miRs can silence genes by binding to families of messenger RNAs that share related biological functions and inhibit their translation into proteins. Thus, a single miR can modulate complex biological processes such as myocardial hypertrophy or inflammation. ${ }^{12}$ Some miRs are even exported from cells into the plasma in the form of membrane bound exosomes in order to transduce inter-cellular signals 14 . Each of these steps in transcription - epigenetic regulation, RNA editing, RNA splicing, regulation by noncoding RNAs, and plasma exosomal miRs — can be quantified genome-wide using available technologies, providing vast opportunities for biomarker development.

In clinical applications, however, there are three commonly used methods for assessing transcriptomes:quantitative real-time polymerase chain reaction (qRT-PCR, or qPCR), microarrays, and RNA sequencing (RNAseq). qPCRmethods use short DNA sequences 
called primers to anneal to and allow amplification of known transcripts in a biological sample. 15 Automation has enabled rapid quantitation of anywhere from a handful to a few hundred transcripts using qPCR, provided that sequences of the transcripts of interest are known. These methods are inexpensive, suitable for assaying a large number of samples, and provide an accurate assessment of gene expression. Their primary limitation is a requirement to focus on a limited panel of candidate transcripts.

In microarray-based methods, ${ }_{-}^{6} \mathrm{RNA}$ is isolated from a specific sample and converted to a chemically labeled form. Labeled RNA is then incubated with a small chip that contains an array of short sequences that correspond to known transcripts. Transcript abundance is assessed by hybridization of labeled sampled to each of the probes on the microarray. Microarraysoffer genome-wide coverage of the transcriptome, have high throughput, and have become relativelyinexpensive. They are limited by the requirement to know existing transcript sequences up front, offer a limited dynamic range, and require complicated normalization methods.Despite theselimitations, microarrays have thus far been the most widely applied technology to perform transcriptome-wide surveys in heart disease.

The most recently developed methods for transcriptomic assessment rely on RNA sequencing (RNAseq)._ In this approach the total complement of RNAs from a given sample is isolated and sequenced at great depth using extremely high throughput technologies (often called Next-Generation Sequencing ${ }^{16}$ ). The abundance of each transcript is then ascertained by counting the number of copies. RNAseq has the advantages of 'digital' as opposed to 'analogue' quantitation and no requirement to design probes prior to sequencing. In addition, RNAseq offers vastly more information regarding the human transcriptome than previous technologies, including the ability to assess the impact of DNA variants on gene expression, unbiased discovery of novel transcripts and splice isoforms, and RNA editing. The challenges for RNAseq are complex sample preparation, cost, and the enormous computational capacity required to processthe large volumes of sequence data produced by even small experiments. ${ }_{17}^{17}$ RAseq has already begun to supplant microarrays in the research world, but clinical studies will likely use both approaches for some time depending on the balance between scientific goals, sample size, and cost. Looking forward, it is clear that advances in ourfundamental understanding of gene transcription and rapidly advancing techniques for transcriptome assessment will have a continued impact on biomarker development.

\section{Transcriptomics in the circulation versus primary tissues}

Determining which cells or tissue should be used to study transcriptome changes associated with cardiovascular pathology is the first hurdle in identifying biomarkers that can be reliably used for screening, prognosis, or therapeutic targeting. Blood-derived RNA sources, such whole blood RNA, lymphoblastoid cell lines (LCL), and peripheral blood mononuclear cells (PBMC), have been widely used in gene expression studies for biomarker identification and are an optimal source due to easy accessibility. Whitney et al described circulating leukocytes as scouts, continuously maintaining a vigilant and comprehensive surveillance of the body for signs of infection or other threats. The gene expression responses of circulating leukocytes can provide an early warning system 18 and have the potential to be diagnostic 
surrogates for systemic conditions. Studies have shown that leukocyte gene expression is measurably changed with stroke, ${ }_{-}^{19}$ hypertension, ${ }_{-}^{20}$ and coronary artery disease..$_{-}^{21}$ This makes blood-derived RNA a valuable resource when studying diseases involving remote target tissues. ${ }_{-2}^{22}$ For diseases with a clear inflammatory component, such as atherosclerosis or organ rejection, blood transcriptomics has the potential to identify both biomarkers and biomediators of disease.

Although circulating cells have easy access, they also have very dynamic expression patterns which can complicate interpretation. A study of blood transcriptomes stability in health subjects revealed distinct patterns of inter-subject variability as well as and temporal variability within subjects in the absence of disease. Contributors to expression variability included differences in the cellular composition of the blood sample, as well as gender, age, and time of day. 18 Other concerns for using peripheral blood include standardization of blood draws, processing RNA from whole blood and leukocytes_-23 as well as standardizing the microarray technique to insure quality profiling and avoid batch effects. .4

Another promising source also in the circulating plasma ismicroRNA. MicroRNAs (miRs) are endogenous small noncoding regulatory RNAs that typically function as negative regulators of mRNA translation. They are one of the more abundant classes of regulatory genes, comprising $1-4 \%$ of predicted genes in humans, and a single miR can regulate as many as 200 mRNAs. ${ }^{25}$ Altered expression of specific miRs has been associated with a variety of diseases including cancer ${ }^{26}$ and cardiovascular diseases. ${ }^{12}$ As described above, miRs can be excreted from cells in the form of membrane bound exosomes, where they enter the plasma to exert intracellular signaling functions. As such, they can be quantified in plasma using PCR based methods, thereby providing an entirely new class of plasma biomarkers. Recent studies indicate that circulating miRs displayed remarkable stability 27 and resistance to degradation from endogenous RNAse activity_z making them favorable targets for clinical assays.

Although less convenient from a clinical standpoint, transcriptome assessment in primary tissues such as myocardium allows a more direct window into cardiac disease. Early cardiac microarray studies used myocardial tissue obtained at the time of cardiac transplantation 29 or LVAD placement $\underline{30}$ to identify myocardial transcripts associated with advanced heart failure or reverse remodeling. Numerous genes of interest have been identified in this fashion, revealing signaling pathways that may contribute to heart failure, 1 and some have even led to development of novel therapeutic approaches.Use of the human cardiac transcriptome as a biomarker to improve diagnosis has been piloted for identifying specific causes of cardiomyopathy ${ }_{-}^{29}$ or subtypes of myocarditis,, 34 but their clinical use has been slow to develop due to risks associated with endomyocardial biopsy. ${ }^{35}$ Under current guidelines, endomyocardial biopsy in clinical care is only recommended under narrow circumstances, ${ }_{-}^{36}$ but it is conceivable that broader use coupled with assessment of the myocardial transcriptome could aid in reclassification of cardiomyopathies. Until broader use of endomyocardial biopsy is revisited, the question of whether the myocardial transcriptome would be clinically useful will remain unanswered. 


\section{Cardiovascular Biomarkers Discovered through transcriptomics}

Numerous researchers have utilized transcriptomic approaches to identify novel cardiovascular biomarkers. Here we highlight examples that have begun to influence clinical practice or that illustrate emerging approaches.

\section{Soluble ST2}

Weinberg et al. performed a transcriptomic screen to identify genes that were induced in cardiac myocytes in response to myocardial stretchin vitro. 37 One of their most provocative findings was increased transcription of the ST2 receptor in response to stretch. The ST2 protein exists in a soluble form that can be measured in peripheral blood, and ensuing work over the past decade has revealed that soluble ST2 is markedly elevated in heart failure patients, and can aid in risk stratification of both acute -38 and chronic heart failure. $\frac{39}{-}$ The U.S. Food and Drug Administrationhas recently cleared a commercial grade soluble ST2 assay (Presage ${ }^{\mathrm{TM}}$ ) for use to assess prognosis in chronic heart failure. Moreover, follow-up studies in animals have suggested that ST2 is part of a cardioprotective paracrine signals between cardiac fibroblasts and myocytes, suggesting therapeutic approaches. Thus the initial findings of a microarray screen have led to both a novel cardiac biomarker and therapeutic target for heart failure. .34

\section{Blood Gene Expression in Cardiac Allograft Rejection}

Cardiac allograft rejection is the major clinical concern in heart transplant recipients. Since rejection is a systemic immune response, it is reasonable to hypothesize that the peripheral blood transcriptome can gauge organ level rejection. By applying whole genome transcriptomics to a single-center cohort of cardiac transplant recipients, our group proved the concept that clinically significant allograft rejection could be identified and tracked via monitoring of the peripheral blood transcriptome. 2 In a larger, multicenter study, Deng et al use a lymphocyte-specific transcriptome array to identify an 11-gene panel that was able to distinguish biopsy-proven moderate/severe rejection with excellent sensitivity and good specificity. ${ }_{-}$This assay has been refined into a qPCR panel called AlloMap ${ }^{\mathrm{TM}}$ that is now commercially available. AlloMap ${ }^{\mathrm{TM}}$ integrates expression levels of 20 genes (11 informative, 9 normalization controls) by qPCR and provides a score ranging from 0 to 40, with lower scores being associated with a very low likelihood of clinically significant allograft rejectiondefined by Grade $33 \mathrm{~A} / 2 \mathrm{R}$ according to the original/revised International Society of Heart and Lung Transplantation (ISHLT) classification. Notably,the Invasive Monitoring Attenuation through Gene Expression (IMAGE) clinical trial compared the routine use of endomyocardial biopsies rejection monitoring with a more selective use of endomyocardial biopsy guided by AlloMap ${ }^{\mathrm{TM}}$ and noninvasive cardiac imaging.Both strategies resulted in equivalent clinical outcomes, but patients who were monitored with gene-expression profiling underwent far fewer biopsies per person-year of follow-up than did patients who were monitored with routine biopsy ( 0.5 vs. 3.0, $\mathrm{P}<0.001)$.It is important to understand the limitations of AlloMap ${ }^{\mathrm{TM}}$, which has a high negative predictive value and is therefore primarily helpful in identifying patients with low probability of rejection. Research is ongoing to correlate post-transplant ischemic injury and transplant vasculopathy ${ }_{-}^{45}$ with AlloMap ${ }^{\mathrm{TM}}$ scores, which appears to be elevated in both clinical scenarios.Although heart 
transplant recipients are a niche population, the successful development of blood gene expression biomarkers to monitor transplant recipients is one of the best examples of clinical cardiovascular transcriptomics to date.

\section{Blood Gene Expression in Coronary Artery Disease}

Like allograft rejection, coronary artery disease also has a substantial inflammatory component. Investigators have appliedthe paradigm of peripheral blood transcriptome assessment used in the transplant population to develop a gene expression predictor of obstructive coronary artery disease. Using a combination of microarrays and qPCR, the Personalized Risk Evaluation and Diagnosis In the Coronary Tree (PREDICT) study developed and validated a 23-gene, expression-based classification test for diagnosis of obstructive $\mathrm{CAD}$ in patients with chest discomfort. ${ }^{21}$ This gene expression test is now commercially available as the CORUS CAD ${ }^{\mathrm{TM}}$ assay. The test is limited to patients with chest pain who do not have diabetes, chronic inflammatory disorders, elevated levels of leukocytes, or acute coronary syndromes by conventional protein biomarkers. Although the CORUS $^{\mathrm{TM}}$ assay is extremely promising, widespread implementation of a coronary disease gene expression test competes with established noninvasive approaches to diagnosis. The added value of a transcriptomic profile such as CORUS ${ }^{\mathrm{TM}}$ must be rigorously tested against these existing noninvasive standards and explored in a variety of different populations to define its clinical utility.

\section{Plasma miRs}

Over the past ten years, basic studies have uncovered a convincing role for miRs in the pathogenesis of most cardiovascular conditions. As qPCR techniques for quantifying plasma miRs continue to improve, studies exploring whether any of these candidates can serve as clinical biomarkers have begun to emerge. These include studies associating levels of selected miRs with presence of acute coronary syndrome, ${ }_{-}^{46}$ acute myocardial infarction, ${ }^{47-49}$ type II diabetes, ${ }_{-}$hypertension,,-51 and heart failure among others. The majority of these studies are small proof of concept studies, and further work in larger populations is required.

\section{Conclusions}

Over the past ten years, transcriptomics has had a substantial impact on the field of cardiovascular biomarkers, and several transcriptome biomarkers are now approved for clinical use. Several lessons have emerged from this experience. Although a single biomarker is a tangible entity that can be easily understood, transcriptomic studies have shown that aggregate measures comprised of multiple genes are also informative as biomarkers of complex disease.Indeed, the concept of 'multimarker panels' has emerged in other avenues of biomarker research A second lesson is that independent validation of findings in multiple cohorts is required to support the validity of new transcriptomic assays.Just as for genome-wide SNP association studies, 55 genome-wide transcriptome association studies are prone to false positives and replication of initial findings is a required step. Third, it is clear that as technologies progress, whole new categories of biomarkers will continue to emerge. This will be 
particular true as sequencing technologies continue to improve. For example, it is now feasible to detect and sequence cell-free DNA released into the plasma by necrotic tissues, and this has been utilized to detected early rejection of transplanted organs (which contain DNA sequences from the donor that differ those of the recipient) ${ }^{56}$. Since the analyte being measure is DNA and not RNA this is not,strictly speaking, a 'transcriptomic' assay. Yet many of the same principles outlined in this review apply toward developing cell free DNA markers for clinical use.

Finally, the ultimate assessment for clinical application is the same for any biomarker. As nicely outlined by Morrow, clinical potential may be evaluated by asking three fundamental questions: 1) Can the clinician measure the biomarker? 2) Does it add new information? and 3) Does it help the clinician to manage patients? ${ }^{57}$ Research that aims to bring transcriptomic biomarkers to clinical practice must be designed to answer these questions in a direct and convincing way. Ideally, this would require a randomized trial, such as the IMAGE study, comparing use versus non-use of the biomarker to ascertain whether or not it contributes in a meaningful way to patient outcome.

\section{Acknowledgments}

Funding: Supported in part by NIH grants R01HL105993 and R01HL088577

\section{References}

1. Feero WG, Guttmacher AE, Collins FS. Genomic medicine -- an updated primer. N.Engl.J.Med. 2010; 362:2001-2011. [PubMed: 20505179]

2. Musunuru K, Kathiresan S. Genetics of coronary artery disease. Annual Review of Genomics and Human Genetics. 2010; 11:91-108.

3. Cappola TP, Dorn GW 2nd. Clinical considerations of heritable factors in common heart failure. Circ Cardiovasc Genet. 2011; 4:701-709. [PubMed: 22187448]

4. Ashley EA, Butte AJ, Wheeler MT, Chen R, Klein TE, Dewey FE, Dudley JT, Ormond KE, Pavlovic A, Morgan AA, Pushkarev D, Neff NF, Hudgins L, Gong L, Hodges LM, Berlin DS, Thorn CF, Sangkuhl K, Hebert JM, Woon M, Sagreiya H, Whaley R, Knowles JW, Chou MF, Thakuria JV, Rosenbaum AM, Zaranek AW, Church GM, Greely HT, Quake SR, Altman RB. Clinical assessment incorporating a personal genome. Lancet. 2010; 375:1525-1535. [PubMed: 20435227]

5. Cappola TP, Margulies KB. Functional genomics applied to cardiovascular medicine. Circulation. 2011; 124:87-94. [PubMed: 21730321]

6. Quackenbush J. Microarray analysis and tumor classification. N.Engl.J.Med. 2006; 354:2463-2472. [PubMed: 16760446]

7. Wang Z, Gerstein M, Snyder M. Rna-seq: A revolutionary tool for transcriptomics. Nat Rev Genet. 2009; 10:57-63. [PubMed: 19015660]

8. Baccarelli A, Rienstra M, Benjamin EJ. Cardiovascular epigenetics. Circulation: Cardiovascular Genetics. 2010; 3:567-573. [PubMed: 21156932]

9. Keren H, Lev-Maor G, Ast G. Alternative splicing and evolution: Diversification, exon definition and function. Nat Rev Genet. 2010; 11:345-355. [PubMed: 20376054]

10. Li M, Wang IX, Li Y, Bruzel A, Richards AL, Toung JM, Cheung VG. Widespread rna and DNA sequence differences in the human transcriptome. Science. 2011; 333:53-58. [PubMed: 21596952]

11. Rabani M, Kertesz M, Segal E. Computational prediction of rna structural motifs involved in posttranscriptional regulatory processes. Proc Natl Acad Sci U S A. 2008; 105:14885-14890. [PubMed: 18815376] 
12. Small EM, Frost RJ, Olson EN. Micrornas add a new dimension to cardiovascular disease. Circulation. 2010; 121:1022-1032. [PubMed: 20194875]

13. Rinn JL, Chang HY. Genome regulation by long noncoding rnas. Annual review of biochemistry. 2012; 81:145-166.

14. Valadi H, Ekstrom K, Bossios A, Sjostrand M, Lee JJ, Lotvall JO. Exosome-mediated transfer of mrnas and micrornas is a novel mechanism of genetic exchange between cells. Nat Cell Biol. 2007; 9:654-659. [PubMed: 17486113]

15. Mayer G, Muller J, Lunse CE. Rna diagnostics: Real-time rt-pcr strategies and promising novel target rnas. Wiley interdisciplinary reviews. RNA. 2011; 2:32-41. [PubMed: 21956968]

16. Dewey FE, Pan S, Wheeler MT, Quake SR, Ashley EA. DNA sequencing: Clinical applications of new DNA sequencing technologies. Circulation. 2012; 125:931-944. [PubMed: 22354974]

17. Chen R, Mias GI, Li-Pook-Than J, Jiang L, Lam HY, Miriami E, Karczewski KJ, Hariharan M, Dewey FE, Cheng Y, Clark MJ, Im H, Habegger L, Balasubramanian S, O'Huallachain M, Dudley JT, Hillenmeyer S, Haraksingh R, Sharon D, Euskirchen G, Lacroute P, Bettinger K, Boyle AP, Kasowski M, Grubert F, Seki S, Garcia M, Whirl-Carrillo M, Gallardo M, Blasco MA, Greenberg PL, Snyder P, Klein TE, Altman RB, Butte AJ, Ashley EA, Gerstein M, Nadeau KC, Tang H, Snyder M. Personal omics profiling reveals dynamic molecular and medical phenotypes. Cell. 2012; 148:1293-1307. [PubMed: 22424236]

18. Whitney AR, Diehn M, Popper SJ, Alizadeh AA, Boldrick JC, Relman DA, Brown PO. Individuality and variation in gene expression patterns in human blood. Proc Natl Acad Sci U S A. 2003; 100:1896-1901. [PubMed: 12578971]

19. Tang YLA, Aronow BJ, Sharp FR. Blood genomic responses differ after stroke, seizures, hypoglycemia, and hypoxia: Blood genomic fingerprints of disease. Ann Neurol. 2001; 50:699_ 707. [PubMed: 11761467]

20. Chon HGC, van der Meijden BB, Dijstelbloem HM, Kraaijenhagen RJ, van Leenen D, Holstege FC, Joles JA, Bluyssen HA, Koomans HA, Braam B. Broadly altered gene expression in blood leukocytes in essential hypertension is absent during treatment. Hypertension. 2004; 43:947-951. [PubMed: 15007037]

21. Rosenberg S, Elashoff MR, Beineke P, Daniels SE, Wingrove JA, Tingley WG, Sager PT, Sehnert AJ, Yau M, Kraus WE, Newby LK, Schwartz RS, Voros S, Ellis SG, Tahirkheli N, Waksman R, McPherson J, Lansky A, Winn ME, Schork NJ, Topol EJ. Multicenter validation of the diagnostic accuracy of a blood-based gene expression test for assessing obstructive coronary artery disease in nondiabetic patients. Annals of internal medicine. 2010; 153:425-434. [PubMed: 20921541]

22. Rockett JC, Burczynski ME, Fornace AJ, Herrmann PC, Krawetz SA, Dix DJ. Surrogate tissue analysis: Monitoring toxicant exposure and health status of inaccessible tissues through the analysis of accessible tissues and cells. Toxicology and applied pharmacology. 2004; 194:189199. [PubMed: 14736499]

23. Feezor RJ, Baker HV, Mindrinos M, Hayden D, Tannahill CL, Brownstein BH, Fay A, MacMillan S, Laramie J, Xiao W, Moldawer LL, Cobb JP, Laudanski K, Miller-Graziano CL, Maier RV, Schoenfeld D, Davis RW, Tompkins RG. Whole blood and leukocyte rna isolation for gene expression analyses. Physiol Genomics. 2004; 19:247-254. [PubMed: 15548831]

24. Leek JT, Scharpf RB, Bravo HC, Simcha D, Langmead B, Johnson WE, Geman D, Baggerly K, Irizarry RA. Tackling the widespread and critical impact of batch effects in high-throughput data. Nat Rev Genet. 2010; 11:733-739. [PubMed: 20838408]

25. Lewis BP, Shih IH, Jones-Rhoades MW, Bartel DP, Burge CB. Prediction of mammalian microrna targets. Cell. 2003; 115:787-798. [PubMed: 14697198]

26. Esquela-Kerscher A, Slack FJ. Oncomirs - micrornas with a role in cancer. Nature reviews. Cancer. 2006; 6:259-269.

27. Weber JA, Baxter DH, Zhang S, Huang DY, How Huang K, Jen Lee M, Galas DJ, Wang K. The microrna spectrum in 12 body fluids. Clin. Chem. 2010; 56:1733-1741. [PubMed: 20847327]

28. Tsui NBY, Ng EKO, Lo YMD. Stability of endogenous and added rna in blood specimens, serum, and plasma. Clin. Chem. 2002; 48:1647-1653. [PubMed: 12324479]

29. Kittleson MM, Ye SQ, Irizarry RA, Minhas KM, Edness G, Conte JV, Parmigiani G, Miller LW, Chen Y, Hall JL, Garcia JG, Hare JM. Identification of a gene expression profile that differentiates 
between ischemic and nonischemic cardiomyopathy. Circulation. 2004; 110:3444-3451. [PubMed: 15557369]

30. Margulies KB, Matiwala S, Cornejo C, Olsen H, Craven WA, Bednarik D. Mixed messages: Transcription patterns in failing and recovering human myocardium. Circ.Res. 2005; 96:592-599. [PubMed: 15718504]

31. Hannenhalli S, Putt ME, Gilmore JM, Wang J, Parmacek MS, Epstein JA, Morrisey EE, Margulies $\mathrm{KB}$, Cappola TP. Transcriptional genomics associates fox transcription factors with human heart failure. Circulation. 2006; 114:1269-1276. [PubMed: 16952980]

32. Chen Y, Park S, Li Y, Missov E, Hou M, Han X, Hall JL, Miller LW, Bache RJ. Alterations of gene expression in failing myocardium following left ventricular assist device support. Physiol Genomics. 2003; 14:251-260. [PubMed: 12824457]

33. Japp AG, Cruden NL, Barnes G, van GN, Mathews J, Adamson J, Johnston NR, Denvir MA, Megson IL, Flapan AD, Newby DE. Acute cardiovascular effects of apelin in humans: Potential role in patients with chronic heart failure. Circulation. 2010; 121:1818-1827. [PubMed: 20385929]

34. Heidecker B, Kittleson MM, Kasper EK, Wittstein IS, Champion HC, Russell SD, Hruban RH, Rodriguez ER, Baughman KL, Hare JM. Transcriptomic biomarkers for the accurate diagnosis of myocarditis. Circulation. 2011; 123:1174-1184. [PubMed: 21382894]

35. Felker GM, Hu W, Hare JM, Hruban RH, Baughman KL, Kasper EK. The spectrum of dilated cardiomyopathy. The johns hopkins experience with 1,278 patients. Medicine. 1999; 78:270-283. [PubMed: 10424207]

36. Cooper LT, Baughman KL, Feldman AM, Frustaci A, Jessup M, Kuhl U, Levine GN, Narula J, Starling RC, Towbin J, Virmani R. Endorsed by the Heart Failure Society of A, the Heart Failure Association of the European Society of $\mathrm{C}$. The role of endomyocardial biopsy in the management of cardiovascular disease: A scientific statement from the american heart association, the american college of cardiology, and the european society of cardiology. Circulation. 2007; 116:2216-2233. [PubMed: 17959655]

37. Weinberg EO, Shimpo M, De Keulenaer GW, MacGillivray C, Tominaga S, Solomon SD, Rouleau JL, Lee RT. Expression and regulation of st2, an interleukin-1 receptor family member, in cardiomyocytes and myocardial infarction. Circulation. 2002; 106:2961-2966. [PubMed: 12460879]

38. Januzzi JL Jr. Peacock WF, Maisel AS, Chae CU, Jesse RL, Baggish AL, O'Donoghue M, Sakhuja R, Chen AA, van Kimmenade RR, Lewandrowski KB, Lloyd-Jones DM, Wu AH. Measurement of the interleukin family member st2 in patients with acute dyspnea: Results from the pride (probrain natriuretic peptide investigation of dyspnea in the emergency department) study. J Am Coll Cardiol. 2007; 50:607-613. [PubMed: 17692745]

39. Ky B, French B, McCloskey K, Rame JE, McIntosh E, Shahi P, Dries DL, Tang WH, Wu AH, Fang JC, Boxer R, Sweitzer NK, Levy WC, Goldberg LR, Jessup M, Cappola TP. High-sensitivity st2 for prediction of adverse outcomes in chronic heart failure. Circ Heart Fail. 2011; 4:180-187. [PubMed: 21178018]

40. Sanada S, Hakuno D, Higgins LJ, Schreiter ER, McKenzie AN, Lee RT. Il-33 and st2 comprise a critical biomechanically induced and cardioprotective signaling system. J.Clin.Invest. 2007; 117:1538-1549. [PubMed: 17492053]

41. Kakkar R, Lee RT. The il-33/st2 pathway: Therapeutic target and novel biomarker. Nat.Rev.Drug Discov. 2008; 7:827-840. [PubMed: 18827826]

42. Horwitz PA, Tsai EJ, Putt ME, Gilmore JM, Lepore JJ, Parmacek MS, Kao AC, Desai SS, Goldberg LR, Brozena SC, Jessup ML, Epstein JA, Cappola TP. Detection of cardiac allograft rejection and response to immunosuppressive therapy with peripheral blood gene expression. Circulation. 2004; 110:3815-3821. [PubMed: 15583081]

43. Deng MC, Eisen HJ, Mehra MR, Billingham M, Marboe CC, Berry G, Kobashigawa J, Johnson FL, Starling RC, Murali S, Pauly DF, Baron H, Wohlgemuth JG, Woodward RN, Klingler TM, Walther D, Lal PG, Rosenberg S, Hunt S. Noninvasive discrimination of rejection in cardiac allograft recipients using gene expression profiling. Am.J.Transplant. 2006; 6:150-160. [PubMed: 16433769] 
44. Starling RC, Pham M, Valantine H, Miller L, Eisen H, Rodriguez ER, Taylor DO, Yamani MH, Kobashigawa J, McCurry K, Marboe C, Mehra MR, Zuckerman A, Deng MC. Molecular testing in the management of cardiac transplant recipients: Initial clinical experience. The Journal of Heart and Lung Transplantation. 2006; 25:1389-1395. [PubMed: 17178330]

45. Yamani MH, Taylor DO, Haire C, Smedira N, Starling RC. Post-transplant ischemic injury is associated with up-regulated allomap gene expression. Clinical transplantation. 2007; 21:523-525. [PubMed: 17645713]

46. Widera C, Gupta SK, Lorenzen JM, Bang C, Bauersachs J, Bethmann K, Kempf T, Wollert KC, Thum T. Diagnostic and prognostic impact of six circulating micrornas in acute coronary syndrome. J Mol Cell Cardiol. 2011; 51:872-875. [PubMed: 21806992]

47. D'Alessandra Y, Devanna P, Limana F, Straino S, Di Carlo A, Brambilla PG, Rubino M, Carena MC, Spazzafumo L, De Simone M, Micheli B, Biglioli P, Achilli F, Martelli F, Maggiolini S, Marenzi G, Pompilio G, Capogrossi MC. Circulating micrornas are new and sensitive biomarkers of myocardial infarction. European Heart Journal. 2010; 31:2765-2773. [PubMed: 20534597]

48. Ji X, Takahashi R, Hiura Y, Hirokawa G, Fukushima Y, Iwai N. Plasma mir-208 as a biomarker of myocardial injury. Clin. Chem. 2009; 55:1944-1949. [PubMed: 19696117]

49. Corsten MF, Dennert R, Jochems S, Kuznetsova T, Devaux Y, Hofstra L, Wagner DR, Staessen JA, Heymans S, Schroen B. Circulating microrna-208b and microrna-499 reflect myocardial damage in cardiovascular disease / clinical perspective. Circulation: Cardiovascular Genetics. 2010; 3:499-506. [PubMed: 20921333]

50. Zampetaki A, Kiechl S, Drozdov I, Willeit P, Mayr U, Prokopi M, Mayr A, Weger S, Oberhollenzer F, Bonora E, Shah A, Willeit J, Mayr M. Plasma microrna profiling reveals loss of endothelial mir-126 and other micrornas in type 2 diabetes / novelty and significance. Circulation Research. 2010; 107:810-817. [PubMed: 20651284]

51. Li S, Zhu J, Zhang W, Chen Y, Zhang K, Popescu LM, Ma X, Bond Lau W, Rong R, Yu X, Wang B, Li Y, Xiao C, Zhang M, Wang S, Yu L, Chen AF, Yang X, Cai J. Signature microrna expression profile of essential hypertension and its novel link to human cytomegalovirus infection / clinical perspective. Circulation. 2011; 124:175-184. [PubMed: 21690488]

52. Tijsen AJ, Creemers EE, Moerland PD, de Windt LJ, van der Wal AC, Kok WE, Pinto YM. Mir423-5p as a circulating biomarker for heart failure. Circulation Research. 2010; 106:10351039. [PubMed: 20185794]

53. Latronico MVG, Catalucci D, Condorelli G. Emerging role of micrornas in cardiovascular biology. Circulation Research. 2007; 101:1225-1236. [PubMed: 18063818]

54. Ky B, French B, Levy WC, Sweitzer NK, Fang JC, Wu AH, Goldberg LR, Jessup M, Cappola TP. Multiple biomarkers for risk prediction in chronic heart failure. Circ Heart Fail. 2012; 5:183-190. [PubMed: 22361079]

55. Freely associating. Nat.Genet. 1999; 22:1-2. [PubMed: 10319845]

56. Snyder TM, Khush KK, Valantine HA, Quake SR. Universal noninvasive detection of solid organ transplant rejection. Proc Natl Acad Sci U S A. 2011; 108:6229-6234. [PubMed: 21444804]

57. Morrow DA, de Lemos JA. Benchmarks for the assessment of novel cardiovascular biomarkers. Circulation. 2007; 115:949-952. [PubMed: 17325253] 


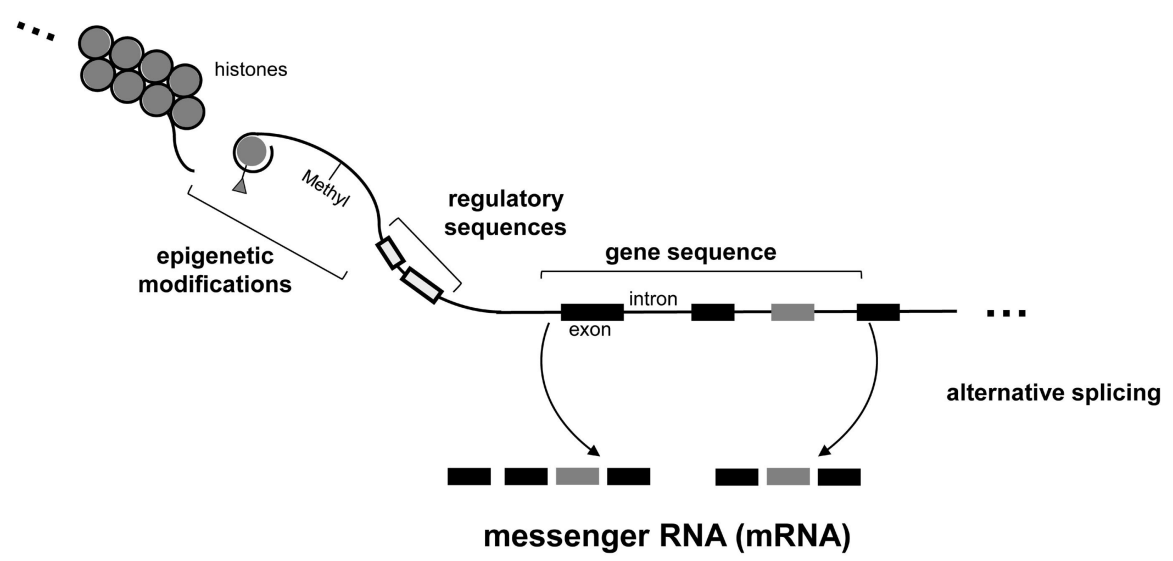

noncoding RNA

(miRNAs)

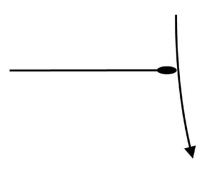

protein

Fig 1.

Schematic overview of gene expression. 